\title{
Oracles and Offerings: The Vernacular Poetry that Binds Gods and Humans
}

\author{
Hirano Tae \\ Translated by Kristopher REEvES
}

I

$\mathrm{n}$ the world of premodern Japanese literature, vernacular poetry was depicted as something capable of transcending the established boundaries of social status and nationality, a vehicle for crossing between different worlds. I would like here to briefly examine the role of vernacular poetry as a means of transcending the borders between gods and humans. On the one hand, the gods give messages to humans by means of oracular verses of vernacular poetry; on the other hand, humans seeks to please the gods by means of offerings of vernacular poetry. It is through these two special forms of presentation-oracles from the gods and offerings to the gods-that vernacular poetry succeeded in blurring the borders between the mundane and the divine.

Tradition would have it that the first vernacular poem - that is, of the conventional type consisting of thirty-one syllables_-was composed by a deity. According to the vernacular preface to Kokin wakashü 古今和歌集 (Poems ancient and modern, 905), the first imperially commissioned anthology of vernacular poetry, this was a poem intoned by the god Susanoo スサノタノミコト when marrying his new bride Kushiinada クシイナダヒメ in the land of Izumo (in modern-day Shimane, see Figure 1).

Thus, avers the preface, began the tradition of thirty-one-syllable vernacular poetry. Since that event, it was not uncommon for gods to recite vernacular poetry, and, more especially, to reveal their intentions to us mortals by means of oracles of the same form. Such verses are known collectively as oracular poems. Let us take a look at the history of those oracular poems preserved in imperially commissioned anthologies of vernacular verse, focusing our attention on ways in which such poems allow the gods and humans to communicate with one another.

The first imperially commissioned anthology of vernacular verse to contain oracular poetry was Shüi wakashü拾遺和歌集 (Gleanings of vernacular verse, 1005), this being the third such anthology. In fascicle ten we find two oracular poems, one by the god at Sumiyoshi Shrine 住吉社 (Osaka), the other by the god presiding 


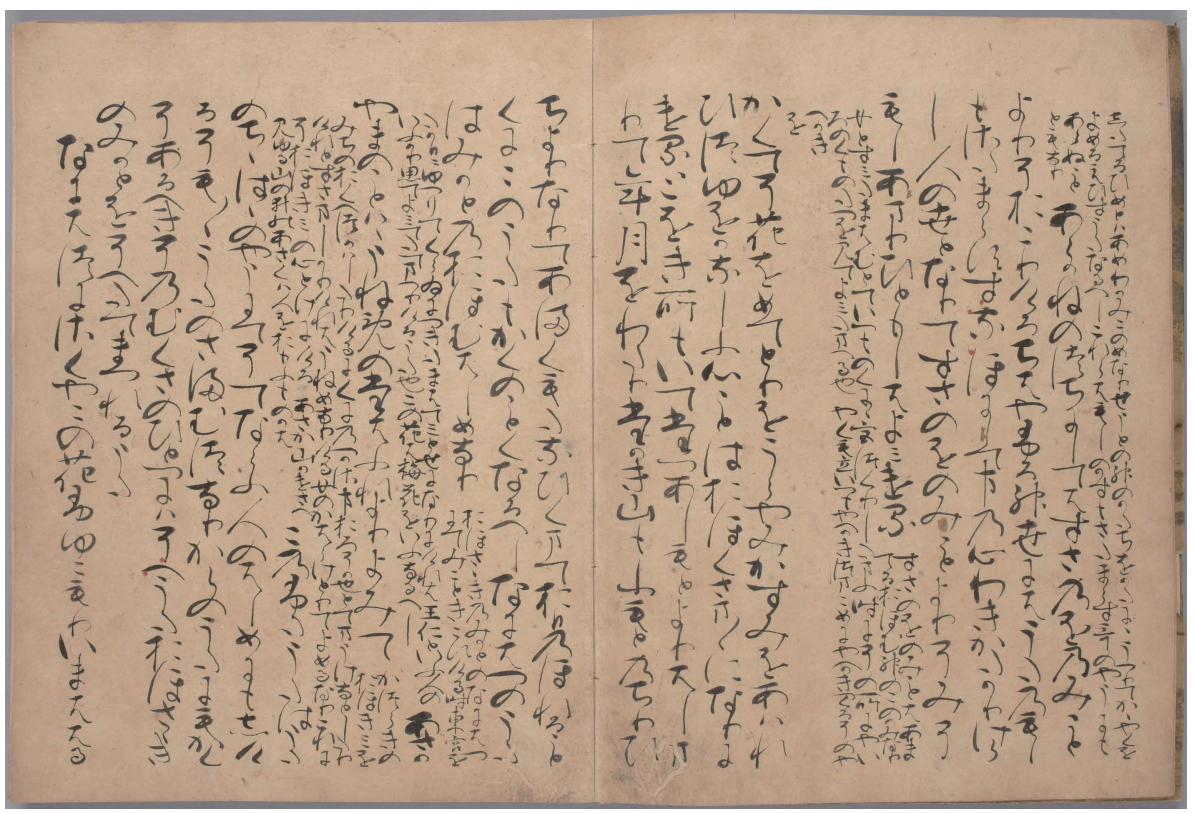

Figure 1. Kokin wakashū, kana-jo 古今和歌集 仮名序. (NIJL, item no. 99-2-1) Eishō 16 (1519), postscript by Reizei Tamehiro 冷泉為広.

Formerly held by Seikei Shooku (Ōshima Masatarō). https://doi.org/10.20730/200003050

over Kamo Shrine 賀茂社 (Kyoto). Both of these poems appear in a section labelled kagura uta 神楽歌, songs performed in divine music. The fourth imperially commissioned anthology, Goshüi wakashü 後拾遺和歌集 (Latergleanings of vernacular verse, 1086), has a small sub-section entitled jingi $i$ 神祇, gods of heaven and earth, which is embraced within the more encompassing category of miscellaneous verse (zoka 雑下). Within this jingi sub-section, the first poem is attributed to the aforementioned Sumiyoshi deity, while the second poem is purported to have been intoned by the god at Kifune Shrine 貴船社 (Kyoto). Kin'yō wakashū 金葉和歌集 (Anthology of golden leaves, 1125), the fifth imperially commissioned anthology, contains no oracular poetry, while the sixth anthology, Shika wakash $\bar{u}$ 詞花和歌集 (Anthology of floral verses, 1151), contains but one oracular poem, attributed to the god of Inari Shrine 稲荷社 (Kyoto), which appears in the second section of miscellaneous poetry (zokea).

As can be seen from this cursory survey, the number of oracular poems appearing in imperially commissioned anthologies of vernacular verse is not great. Even so, interest in oracular poetry was clearly on the rise from the tenth to the twelfth centuries. Minamoto no Toshiyori 源俊頼 (1055-1129), sole compiler of the aforementioned Kin'yo wakashiu, was also the author of a treatise on poetics entitled Toshiyori zuinō 俊頼髄脳 (Toshiyori's poetic essentials, 1113). In this treatise, he includes a total of five oracular poems, two attributed to the god at Sumiyoshi, one 
to the god at Mount Miwa 三輪山 (in Nara), one to the god at Ise Shrine 伊勢社 (Mie), and one to the god at Kifune. Among the numerous treatises on vernacular poetics that had been compiled by the middle of the twelfth century, Fujiwara no Kiyosuke’s 藤原清輔 (1104-1177) Fukuro zōshi 袋草紙 (Poetic miscellany, c. 1159) contains nineteen oracular poems. It would appear from the rich variety of shrine names found in this treatise that Kiyosuke sought to provide readers with a complete list of all those gods to whom oracular poems had been attributed.

Shortly after Kiyosuke completed his Fukuro zōshi, he set about compiling what was intended to become the seventh imperially commissioned anthology of vernacular verse, Shokushika wakashü 続詞花和歌集 (Second anthology of floral verses, 1165). Emperor Nijō 二条天皇 (1143-1165, r. 1158-1165), the man who originally commissioned this anthology, passed away before its completion, thereby technically precluding its inclusion as one of the imperially commissioned anthologies. Whatever the case, in this anthology, Kiyosuke saw fit to expand what had been, in previous anthologies, but a small section of poems attributed to the gods, into an entire fascicle all its own. Interest among courtly poets in oracular verses had reached a peak in the second half of the twelfth century.

On the other hand, Senzai wakashü 千載和歌集 (Verses for a thousand years, 1188), which became by default the seventh imperially commissioned anthology of vernacular poetry, while containing a section on poems associated with the gods, did not contain a single oracular poem. Instead, we see here many poems composed by humans as offerings to the gods. Here we see, also, poems of petition, praying to the gods for protection, as well as poems composed to commemorate wishes graciously fulfilled by the gods. These latter verses contain explanatory headnotes, the substance of which approaches what would later develop into a genre of anecdotal literature devoted to praising the miraculous efficacy of poetry in gaining divine favor (katoku setsuwa 歌徳説話). Vernacular poetry, in the form of a pious offering, thus came to serve as a powerful means of procuring the god's protection. This practice had already become quite popular about a decade before Senzai wakashū was commissioned. Poetry competitions in which vernacular verses were dedicated as offerings to various gods had been held at Sumiyoshi Shrine (in 1170), at Hirota Shrine 広田社 (Hyōgo, in 1172), twice at the Shinra Shrine in Mii Temple 三井寺新羅社 (Shiga, in 1173 and 1177), and at Kamigamo Shrine 上賀茂社 (Kyoto, in 1178), among others.

At was around this time, too, that the practice of presenting offertory poems to shrine deities took on a further convention: the number of poems offered became set at one hundred (bōnō byakushu 奉納百首). The first such event, hosted by Kamo no Shigeyasu 賀茂重保 (1119-1191), head priest of the Kamo Shrine, and known as the Juei byakushu 寿永百首 (One bundred poems of the Juei era, 1182), gathered together a total of thirty-six poets. Shigeyasu took poems offered during 
both the Juei byakushu and the aforementioned poetry competition held, likewise, at Kamigamo Shrine in 1178, and arranged these into an anthology entitled Tsukimōde wakashü 月詣和歌集 (Verses offered up during monthly visits to the shrine, 1182). Senzai wakashü was completed in 1187 . The man appointed compiler of this imperial anthology was Fujiwara no Toshinari 藤原俊成 (1114-1204). Toshinari had served as an umpire or judge (hanja 判者) at those poetry competitions just mentioned held at Sumiyoshi Shrine, Hirota Shrine, and Kamo Shrine. Six of the thirty-four poems contained in the section of Senzai wakashü relating to the gods were taken from these poetry competitions.

As though to make up for the fact that Senzai wakashiu had not contained any oracular poems, the eighth imperially commissioned anthology of vernacular verse, Shinkokin wakashü 新古今和歌集 ( A new anthology of poems ancient and modern, 1205) has thirteen oracular poems. Not only was this amount unprecedented, but the fact that these poems were placed at the very beginning of the section on poems relating to the gods also reveals an unprecedented interest in such verses. Why, we might rightly ask, are there so many oracular poems in Sbinkokin wakashiu? First, it must be noted that most of the thirteen poems were offered at shrines to which Retired Emperor Go-toba 後鳥羽院 (1180-1239, r. 1183-1198), the man who commissioned this anthology, was wont to offer his own vernacular poems. Considering Go-toba presented his offertory poems both prior to and after the compilation of Shinkokin wakashü, Asada Tōru 浅田徹 Argues that the retired emperor conceived of vernacular poetry as a form of prayer, and that he saw the compilation of this poetry anthology as a means of asking for peace and prosperity throughout his domain. ${ }^{1}$ If this interpretation does indeed approach Go-toba's state of mind at the time of compilation, it is easy to understand why he would have showed exceptional interest in oracular poems, poems which represented the god's replies to his earnest prayers.

As has been shown, Senzai wakashü places importance on offertory poems, to human petitions for divine favor, while Shinkokin wakashü, on the contrary, shows more concern for oracular poems, that is, to the divine replies of human prayers. In either case, vernacular verse, with its ability to transcend the borders between gods and humans, was used as a means for the emperor to pray for a peaceful reign. Vernacular poetry allowed for the voices of humanity to reach the ears of the gods, and for the gods, in their turn, to have their voices heard amidst mortal ears.

${ }^{1}$ Asada Tōru, “Gotoba-in to kami: Shinkokinshū ni taku sareta mono” 後鳥羽院と神一『新古 今集』に託されたもの一, in Kokugakuin rasshi 国学院雑誌, 114: 8 (August 2013) 29-48. 